\title{
EFEKTIVITAS EKSTRAK DAUN SIRSAK DAN DAUN PEPAYA DALAM PENGENDALIAN Plutella xylostella L. (Lepidoptera; Yponomeutidae) PADA TANAMAN KUBIS DI KOTA TOMOHON
}

\author{
Mayestic Silverly Chintami Mawuntu ${ }^{1)}$ \\ ${ }^{1)}$ Program Studi Entomologi Pasca Sarjana, Universitas Sam Ratulangi, Manado \\ e-mail : esty.mawuntu@gmail.com
}

\begin{abstract}
ABSTRAK
Tanaman Kubis merupakan salah satu tanaman yang banyak dibudidayakan di Kota Tomohon, Sulawesi Utara. Plutella xylostella L. adalah salah satu hama utama tanaman ini. Larva merusak tanaman saat berumur 2-6 minggu, dengan memakan permukaan bawah daun tanaman sampai pada kerusakan berat sehingga tanaman tidak dapat tumbuh normal ataupun dijual. Penelitian untuk mengetahui efektivitas pemberian ekstrak daun sirsak dan daun papaya terhadap mortalitas larva $P$. xylostella telah dilakukan dari bulan Juli sampai November 2015. Penelitian menggunakan Rancangan Acak Lengkap dengan 5 perlakuan konsentrasi yaitu Kontrol (0\%), 5\%, $10 \%, 15 \%$ dan $20 \%$. Masing-masing dengan 5 ulangan. Hasil penelitian menunjukkan semakin tinggi konsentrasi ekstrak, semakin tinggi pula angka mortalitas larva $P$. xylostella. Dari hasil pengamatan menunjukkan pemberian ekstrak daun sirsak dan daun papaya efektif dalam mematikan larva hama $P$. xylostella dengan angka mortalitas tertinggi sebanyak $100 \%$ pada masing-masing perlakuan dengan konsentrasi ekstrak $20 \%$.
\end{abstract}

Kata Kunci : Tanaman Kubis; Insektsida nabati; Plutella xylostella

\section{THE EFFECTIVENESS OF EXTRACT SOURSOP LEAF AND PAPAYA LEAF IN CONTROL Plutella xylostella L. (Lepidoptera; Yponomeutidae) ON CABBAGE PLANTS IN TOMOHON CITY}

\begin{abstract}
Cabbagge is well-known plant that widely growth in Tomohon City, North Sulewesi. Plutella xylostella $\mathrm{L}$. is one of the major pests on Cabbagge. Larvae damage the plant since 2-6 weeks old plants by eating the surface of the leaves until severe damages so the plants couldnot grow normally, neither to sell. The study was to verify effectivity of soursop leaves and papaya leaves ecstract to P. xylostella mortality that have been conducted from July to November 2015. The study used completely randomized design with 5 treatments and 5 replications with leaf ecstract consentrations used were $0 \%$ as control, 5\%, 10\%, 15\% and 20\%. The result from the observations showed that the test result of Soursop leaves and Papaya leaves ecstract showed a highly significant from each treatments to larvae mortality of $P$. xylostella. Higher concentrations of ecstract showed more higher mortality of $P$. xylostella larvae. This research also showed that rate number of $P$. xylostella mortality at each ecstract were at $20 \%$ concentration of Soursop leaves and papaya leaves ecstract.
\end{abstract}

Keywords : Cabbages; Biopesticides; Plutella xylostella

\section{PENDAHULUAN}

Provinsi Sulawesi Utara merupakan daerah yang kaya akan keanekaragaman hayati, termasuk didalamnya kekayaan akan tumbuhan yang berfungsi sebagai bahan pangan, bahan obat, tanaman hias dan berbagai fungsi untuk keperluan kebutuhan manusia dan pengembangan usaha pertanian.
Salah satu daerah di propinsi ini yang berpotensi dalam pengembangan usaha pertanian adalah kota Tomohon. Tanah subur didaerah ini menunjukkan potensi dalam pengembangan produksi hasil pertanian, termasuk untuk tanaman hortikultura. Beberapa produk utama hortikultura yaitu: 
Sawi, Bawang, Wortel, Kubis, Cabai, Tomat, dan sebagainya, telah berhasil dikembangkan dan menjadi produk signatur pertanian untuk kota Tomohon.

Salah satu masalah utama dalam usaha produksi tanaman kubis di Kota Tomohon adalah adanya serangan hama ulat daun Plutella xylostella. Hama P. xylostella merupakan hama utama pada tanaman kubis. Pada saat angka populasi tinggi, larva memakan semua daun dan hanya meninggalkan tulang-tulang daun, sehingga terjadi kerusakan berat. Serangga hama ini bisa membuat kerusakan 20-30\% pada tanaman kubis, bahkan sangat merusak sampai produk tanaman ini tidak bisa lagi dijual (Daryanto $d k k ., 1998$ ).

Upaya yang dilakukan petani di kota Tomohon untuk mengendalikan hama pada tanaman kubis selalu menggunakan insektisida kimiawi. Berdasarkan informasi BP4K kota Tomohon, para petani selalu menggunakan insektisida kimia untuk menjaga tanaman dari serangan hama. Aplikasi pestisida dimulai dari pembibitan. Bahkan penggunaan insektisida didasarkan bukan pada ada tidaknya serangan hama, melainkan berdasarkan pengalaman atau kebiasaan saja (BP4K Tomohon, 2015).

Salah satu alternatif yang dapat dilakukan untuk mengatasi masalah tersebut adalah dengan memanfaatkan berbagai senyawa kimia alami yang berasal dari tumbuhan. Pemanfaatan insektisida nabati selain dapat mengurangi dampak pencemaran lingkungan, bahannya mudah di dapat, dan harganya relatif lebih murah apabila dibandingkan dengan pestisida kimia (Untung, 1996; Sudarmo, 2005). Pemanfaatan bahan tumbuhan bisa mengurangi bahaya untuk kesehatan manusia dan ternak dan pengurangan biaya produksi untuk penggunaan pestisida kimia (Sudarmo, 2005)

Jenis tumbuhan yang dapat dijadikan insektisida nabati antara lain adalah tanaman Sirsak dan Pepaya. Tanaman sirsak (Annona muricata L.) memiliki senyawa kimia seperti flavonoid, saponin, tanin, glikosida, annonain, dan senyawa lainnya yang diketahui bisa bertindak sebagai antifeedant, racun kontak dan racun perut bagi beberapa hama tanaman (Noorbetha $d k k, 2013$; Fathanah, 2013). Kotaro Konno et al., (2004) melaporkan bahwa getah pada tanaman pepaya (Carica papaya L.) mengandung kelompok enzim protease seperti papain dan kimopapain, serta menghasilkan senyawasenyawa golongan alkaloid, terpenoid, flavonoid dan asam amino yang sangat beracun bagi beberapa serangga.

Berdasarkan uraian tersebut, maka tujuan penelitian ini adalah untuk mengetahui efektivitas pemberian insektisida nabati ekstrak daun sirsak dan daun pepaya terhadap hama $P$. xylostella pada tanaman kubis di Kota Tomohon dan untuk mengetahui konsentrasi ekstrak daun sirsak dan daun pepaya yang paling efektif dalam pengendalian hama $P$. xylostella pada tanaman kubis di Kota Tomohon.

\section{BAHAN DAN METODE}

Penelitian ini dilaksanakan di Laboratorium Hama dan Penyakit Tumbuhan Fakultas Pertanian Universitas Sam Ratulangi Manado. dan dilahan pertanaman Kubis di Desa Rurukan, Kota Tomohon. Penelitian ini dilaksanakan bulan Juli-November 2015.

Bahan yang digunakan yaitu Tanaman kubis berumur 2 minggu, larva $P$. xylostella instar 3, daun sirsak, daun pepaya, aquades, metanol. Alat-alat yang dipakai yaitu timbangan, aluminium foil, sendok, erlenmeyer $500 \mathrm{ml}$, gelas ukur, pinset, gunting, kain kasa, kertas label, sungkup plastik, kain lap, kertas saring, hand sprayer, label.

Penelitian ini menggunakan Rancangan Acak Lengkap. Dengan 5 perlakuan dan 5 ulangan, dengan susunan perlakuan sebagai berikut:

A0 : Kontrol (konsentrasi 0\%); $100 \mathrm{ml}$ aquades.

A1 : ekstraksi dengan konsentrasi 5\% ; $95 \mathrm{ml}$ aquades, $5 \mathrm{ml}$ ekstrak

A2 : ekstraksi dengan konsentrasi 10\% ; 90 $\mathrm{ml}$ aquades, $10 \mathrm{ml}$ ekstrak

A3 : ekstraksi dengan konsentrasi 15\% ; 85 $\mathrm{ml}$ aquades, $15 \mathrm{ml}$ ekstrak

A4 : ekstraksi dengan konsentrasi 20\% ; 80 $\mathrm{ml}$ aquades, $20 \mathrm{ml}$ ekstrak

Untuk masing-masing perlakuan diberikan notasi :

(A).Ekstrak daun Sirsak.

(B).Ekstrak daun Pepaya.

(C).Ekstrak kombinasi daun Sirsak dan daun Pepaya 
Setiap perlakuan menggunakan 20 ekor larva uji.

\section{Persiapan Lahan dan Pembibitan}

Bibit ditanam pada bedeng yang sudah disiapkan. Tanaman disiram teratur sebanyak 2 kali sehari. Saat tanaman berumur dua minggu. tanaman kemudian dipindahkan ke bedengan yang sudah disiapkan dengan jarak tanam $50 \mathrm{~cm}$ x $40 \mathrm{~cm}$.

Disiapkan 3 bagian lahan dengan pembagian lahan untuk masing-masing percobaan ekstraksi daun sirsak, daun pepaya dan kombinasi daun sirsak-pepaya. Tiap lahan dipilih tanaman kubis sebanyak 25 tanaman, tiap lajur 5 tanaman. Pemeliharaan dilakukan dengan menyiram tanaman dan pengendalian gulma secara mekanis yaitu dengan mencabut gulma yang tumbuh disekitar tanaman.

\section{Pembuatan ekstrak daun}

Daun sirsak dan pepaya diambil sebanyak 1000 gr dicuci bersih dengan air mengalir. Kemudian dikeringanginkan selama 10 hari, sampai menghasilkan berat (gram) daun kering. Bahan kering kemudian diblender sampai menjadi serbuk daun. Serbuk tersebut ditimbang masing-masing sebanyak 200 gram. Untuk perlakuan ekstrak kombinasi daun Sirsak dan daun Pepaya, ditimbang 100 gr serbuk daun Sirsak dan 100 gr serbuk daun Pepaya sehingga total menjadi 200 gr serbuk daun. Selanjutnya serbuk daun masing-masing perlakuan ekstrak direndam dengan pelarut metanol sebanyak $800 \mathrm{ml}$ selama 3x24 jam pada gelas ukur.

Larutan kemudian disaring memakai kertas saring, kemudian diuapkan menggunakan oven dengan suhu $64^{\circ} \mathrm{C}$ selama 3 jam. Hasil ekstrak kemudian dimasukkan dalam wadah dan ditutup dengan aluminium foil dan disimpan dalam lemari es.

\section{Perbanyakan larva $P$. xylostella}

Serangga hama $P$. xylostella dikumpulkan pada saat fase pupa dari tanaman kubis kurang lebih sebanyak 100 pupa untuk keperluan pemeliharaan imago serangga. Sampel penelitian pertama adalah 10 pasang imago $P$. xylostella yang dipilih dengan teknik purposive sampling dari pemeliharaan pupa. Setiap pasang imago dipelihara pada tempat pemeliharaan dan diberi tanaman kubis yang ditanam di dalam polibag sebagai pakan bagi larva dan tempat bertelur bagi imago. Setelah telur menetas, dipelihara larva sampai instar 3.

\section{Pengujian Ekstrak Daun Sirsak}

Pengujian ekstrak dilakukan dengan menyiram tanaman dengan menggunakan hand sprayer yang berisi konsentrasi perlakuan ekstrak. Ekstrak kasar hasil ekstraksi dilarutkan dengan pelarut akuades dengan konsentrasi 5\%, 10\%, $15 \%$ dan $20 \%$. Larutan ekstrak kemudian dimasukkan dalam hand sprayer. Sebelum aplikasi, tanaman terlebih dahulu diberi sungkup plastik untuk mencegah ekstrak tersiram ke tanamn uji lainnya. Waktu penyemprotan dilakukan pada sore hari, dengan kisaran waktu pukul 16.0018.00. Sebelum diinfestasi, larva uji dipuasakan terlebih dahulu selama 3 jam.

\section{Pengamatan dan Analisa Data}

Pengamatan dilakukan terhadap tanaman sampel pada tiap petakan yang ditentukan. Variabel yang diamati adalah mortalitas larva. Pengamatan dilakukan pada satu hari setelah perlakuan dan periode pengamatan dilanjutkan setiap hari setelah aplikasi. Hasil pengamatan dianalisis dengan menggunakan rumus:

$$
\begin{aligned}
\mathrm{M}=\frac{n}{N} & \times 100 \% \\
\text { dengan } \mathrm{M} & : \text { Mortalitas (\%) } \\
n & \text { : Jumlah larva yang mati } \\
N & : \text { Total larva uji }
\end{aligned}
$$

Uji statistik untuk menguji efektivitas ekstrak daun sirsak dan daun pepaya dilakukan dengan Analisis Varians dan dilanjutkan dengan uji BNT 5\%.

\section{HASIL DAN PEMBAHASAN}

\section{Gejala Larva $P$. xylostella yang terinfeksi}

Hasil pengamatan sehari sesudah perlakuan menunjukkan larva $P$. xylostella terlihat kurang aktif dan berkurangnya aktifitas makan. Bahkan beberapa tanaman dengan konsentrasi ekstrak tinggi terlihat tanpa gerekan sama sekali. Hal ini disebabkan oleh senyawa alkaloid dan terpenoid yang sangat berpotensi sebagai penghambat makan dan bersifat toksik sehingga dapat menyebabkan kematian larva. 
Gangguan metabolisme mungkin juga disebabkan oleh terdapatnya senyawa tanin dalam makanan serangga yang dapat mengganggu aktivitas enzim pencernaan serangga (Ambarningrum, 1994; Mahardika $d k k ., 2014$; Salaki $d k k ., 2012)$

Pada larva yang terinfeksi terlihat warna tubuh menjadi hijau muda dan atau kekuningan dari larva normal yang terdapat pada kontrol yang berwarna hijau (Gambar $1)$.

Gambar 1. Perubahan warna pada tubuh larva yang terinfeksi

Jika disentuh tubuh larva menjadi sangat lunak yang kemudian berubah warna menjadi kecoklatan. Larva kemudian mati dan mengering. Larva yang memakan tanaman dengan perlakuan terinfeksi di saluran pencernaan. Hal ini terlihat pada larva yang mati hanya setelah memakan bagian tanaman dengan perlakuan. Setelah larva mati, tubuhnya berubah warna menjadi kecoklatan, mengering dan mengerut dengan integumen yang masih utuh (Gambar 2).

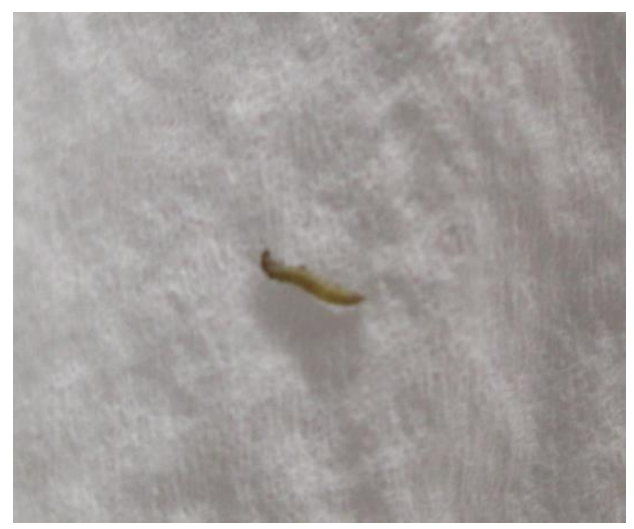

Gambar 2. Larva P. xylostella yang mati

Pada beberapa tanaman dengan perlakuan yang tidak mematikan larva, terlihat larva mampu bertahan hidup bahkan berhasil menjadi pupa, meskipun pupanya berukuran lebih kecil daripada pupa pada perlakuan kontrol.

Wiratno (2010) mengemukakan kerusakan atau cacatnya stadia lanjut $P$. xylostella diduga terjadi akibat senyawasenyawa toksik yang merusak jaringan saraf, seperti senyawa alkaloid yang dapat menghambat proses larva menjadi pupa, serta dapat memutuskan atau dapat menggagalkan metamorfosis hama yang memiliki metamorfosis sempurna.

\section{Mortalitas larva $\boldsymbol{P}$. xylostella setelah aplikasi perlakuan}

\section{A. Daun Sirsak}

Berdasarkan hasil pengamatan, kematian larva terdapat pada tiap konsentrasi perlakuan dengan ekstrak daun sirsak. Hasil uji ini dapat dilihat pada Lampiran 2, yang menunjukkan kematian larva $P$. xylostella pada setiap pengamatan, dengan persentase kematian tertinggi pada konsentrasi perlakuan 20\%. Dari hasil penelitian menunjukkan hubungan antara konsentrasi perlakuan ekstrak dengan angka mortalitas larva $P$. xylostella. Dimana semakin tinggi konsentrasi perlakuan, semakin tinggi pula angka mortalitas larva $P$. xylostella.

Berdasarkan hasil analisis sidik ragam pada Lampiran 5 menunjukkan bahwa penggunaan ekstrak daun Sirsak berpengaruh sangat nyata terhadap mortalitas larva $P$. xylostella. Mortalitas tertinggi pada perlakuan dengan konsentrasi ekstrak $20 \%$ dengan persentase rata-rata mortalitas $81,72 \%$. Hal ini disebabkan tingkat kandungan senyawasenyawa fitokimia yang ada pada konsentrasi tertinggi maka semakin tinggi pula kandungan bahan aktif ektrak daun Sirsak (Arbaningrum, 1998).

Dari data pengamatan terlihat bahwa perlakuan konsentrasi ekstrak dengan angka rata-rata mortalitas larva $P$. xylostella mengalami peningkatan tiap periode pengamatan. Hal ini diduga karena adanya residu yang tertinggal pada tanaman dengan perlakuan ekstrak yang merupakan pakan bagi larva untuk pengamatan selanjutnya

Hasil penelitian menunjukkan bahwa rata-rata mortalitas larva dengan perlakuan ekstrak daun Sirsak lebih tinggi dibandingkan dengan rata-rata mortalitas larva dengan perlakuan ekstrak Pepaya dan perlakuan ekstrak kombinasi daun Sirsak dan Pepaya. 


\section{B. Daun Pepaya}

Berdasarkan hasil pengamatan, kematian larva terdapat pada tiap konsentrasi perlakuan dengan ekstrak daun sirsak. Hasil uji ini dapat dilihat pada Lampiran 3, yang menunjukkan kematian larva $P$. xylostella pada setiap pengamatan, dengan persentase kematian tertinggi pada konsentrasi perlakuan $20 \%$.

Dari hasil penelitian menunjukkan hubungan antara konsentrasi perlakuan ekstrak dengan angka mortalitas larva $P$. xylostella. Dimana semakin tinggi konsentrasi perlakuan, semakin tinggi pula angka mortalitas larva $P$. xylostella.

Berdasarkan hasil analisis sidik ragam pada Lampiran 6 menunjukkan bahwa penggunaan ekstrak daun Sirsak berpengaruh sangat nyata terhadap mortalitas larva $P$. xylostella. Mortalitas tertinggi pada perlakuan dengan konsentrasi ekstrak $20 \%$ dengan persentase rata-rata mortalitas $84,79 \%$.

Ekstrak daun Pepaya memiliki bahan aktif seperti pada ekstrak daun Sirsak, namun ekstrak daun Pepaya juga terdapat enzim papain dan kimo papain yang merupakan racun kontak untuk hama ini. Enzim ini masuk melalui lubang-lubang alami tubuh hama. setelah masuk, racun akan menyebar ke seluruh tubuh dan menyerang sistem saraf sehingga mengganggu aktivitas hama. Enzim papain juga dapat bekerja sebagai enzim protease yang dapat menyerang dan melarutkan komponen penyusun kutikula serangga (Trizelia, 2001). Enzim papain ini juga dapat mempengaruhi beberapa proses fisiologis yang mengatur perkembangan hama (Sastrodihardjo, 1992)

Saponin yang terdapat pada ekstraksi daun sirsak dan pepaya dapat menurunkan aktivitas enzim pencernaan dan penyerapan makanan (Applebaum et al,. 1969). Saponin dapat menurunkan tegangan permukaan selaput kulit larva dan mampu mengikat sterol yang dibutuhkan dalam proses penggantian kulit pada serangga (Gershenzon dan Croteau, 1991 dalam Siahaya $d k k ., 2014$ )

\section{Kombinasi Ekstrak Daun Sirsak dan Daun Pepaya}

Berdasarkan hasil pengamatan, kematian larva terdapat pada tiap konsentrasi perlakuan dengan ekstrak daun sirsak. Hasil uji ini dapat dilihat pada Lampiran 4, yang menunjukkan kematian larva $P$. xylostella pada setiap pengamatan, dengan persentase kematian tertinggi pada konsentrasi perlakuan $20 \%$.

Dari hasil penelitian menunjukkan hubungan antara konsentrasi perlakuan ekstrak dengan angka mortalitas larva $P$. xylostella. Dimana semakin tinggi konsentrasi perlakuan, semakin tinggi pula angka mortalitas larva $P$. xylostella. Hal ini seperti yang terlihat pada data pengamatan mortalitas dengan perlakuan ekstrak daun sirsak dan ekstrak daun papaya.

Berdasarkan hasil analisis sidik ragam pada Lampiran 7 menunjukkan bahwa penggunaan ekstrak daun Sirsak berpengaruh sangat nyata terhadap mortalitas larva $P$. xylostella. Mortalitas tertinggi pada perlakuan dengan konsentrasi ekstrak $20 \%$ dengan persentase rata-rata mortalitas $83,69 \%$.

Meski perlakuan ekstrak kombinasi daun Sirsak dan daun Pepaya menunjukkan angka mortalitas lebih rendah dibandingkan dengan angka mortalitas masing-masing perlakuan ekstrak daun Sirsak dan daun Pepaya (Lampiran 7), tetapi perlakuan ekstrak kombinasi menunjukkan potensi yang sama dalam uji daya bunuh terhadap larva $P$. xylostella seperti pada masing-masing perlakuan ekstrak daun Sirsak dan perlakuan ekstrak daun Pepaya.

\section{KESIMPULAN}

Berdasarkan hasil penelitian, dapat disimpulkan bahwa :

1. Hasil uji ekstrak daun Sirsak dan Pepaya terhadap mortalitas larva $P$. xylostella menunjukkan ekstrak daun sirsak dan daun papaya efektif dalam mengendalikan hama $P$. xylostella.

2. Hasil penelitian menunjukkan bahwa rata-rata mortalitas larva dengan perlakuan ekstrak daun Sirsak lebih tinggi dibandingkan dengan rata-rata mortalitas larva dengan perlakuan ekstrak Pepaya dan perlakuan ekstrak kombinasi daun Sirsak dan Pepaya, yaitu: perlakuan ekstrak daun Sirsak pada konsentrasi $20 \%$ dengan angka rata-rata mortalitas $81,72 \%$, daun Pepaya pada konsentrasi $20 \%$ sebanyak $84,79 \%$ dan ekstrak kombinasi daun Sirsak dan daun Pepaya konsentrasi $20 \%$ sebanyak $83,69 \%$. 


\section{SARAN}

Ekstrak daun Sirsak dan daun Pepaya memiliki potensi yang bisa dikembangkan sebagai pestisida botani terhadap hama Plutella xylostella pada tanaman Kubis, dan juga bisa dikembangkan terhadap hama-hama lain pada tanaman ini.

\section{UCAPAN TERIMA KASIH}

Pada kesempatan ini penulis menyampaikan ucapan terima kasih kepada orang tua dan keluarga, teman-teman dan angkatan program studi Entomologi yang telah mendukung penulis selama penelitian ini, dan juga kepada Direktur dan Koordinator Pasca sarjana UNSRAT. Disampaikan juga terima kasih kepada komisi pembimbing Dr. Ir. Dantje Taroreh, MS Sebagai ketua dan Prof. Dr. Ir. Christina L. Salaki, MS sebagai anggota pembimbing yang membimbing selama penelitian ini.

\section{DAFTAR PUSTAKA}

Badan Penyuluhan Pertanian, Peternakan dan Kehutanan Kota Tomohon. 2015. Data Statistik Produksi dan Kehilangan Hasil Pertanian Kota Tomohon. BP4K Tomohon.

Daryanto,H.,Prabaningrum. L..Purwani. E. T. dan Desmawati. 1998. Pemanfaatan Agens Hayati Parasitoid Diadegma semiclausum Hellen untuk Pengendalian Hama Plutella xylostella $\mathrm{L}$. pada Tanaman Kubis. Direktorat Bina Perlindungan Tanaman. Jakarta.

Kalshoven, L. G. E. 1981. The Pests of Crops in Indonesia. Revised by P. A. Van Deer Lan. PT. Ichtiar Baru, Van Hoeve. Jakarta

Konno, K., Hirayama, C., Tamura, Y., Hattori, M., and K. Kohno. 2004. Papain Protects Papaya Trees from Herbivorous Insects: Role of Cystein Proteases in Latex. Blackwell Publishing Ltd.

Salaki, Christina. L., Evie Paendong, Jantje Pelealu. 2012. Biopestisida Dari Ekstrak Daun Pangi (Pangium sp) Terhadap Serangga Plutella xylostella di Sulawesi Utara.
Fakultas Pertanian UNSRAT. Manado

Tarore, Dantje. 2013. Pengendalian Hama Terpadu; Bahan ajar. Universitas Sam Ratulangi. Manado

Untung. K. 1996. Pengantar Pengelolaan Hama Terpadu. Gadjah Mada University Press. Yogyakarta. 